\title{
New imino-pyridyl nickel (II) complexes: Synthesis, Molecular structures and application as Heck Coupling Catalysts
}

\author{
William M. Motswainyana, Martin O. Onani, Stephen O. Ojwach, Bernard Omondi
}

\begin{abstract}
Reactions of imino-pyridyl ligands, (2-pyridyl-2-thiophenemethyl)imine (L1) and (2pyridyl-2-thiopheneethyl)imine (L2) with $\mathrm{NiBr}_{2}(\mathrm{DME})$ gave the corresponding complexes $\left[\mathrm{Ni}(\mathbf{L 1}) \mathrm{Br}_{2}\right](\mathbf{1})$ and $\left[\mathrm{Ni}(\mathbf{L 2}) \mathrm{Br}_{2}\right]$ (2) in good yields. Treatment of $\mathbf{1}$ and $\mathbf{2}$ with one equivalent of 2-hydroxythiophenol resulted in the displacement of the bromide ligands to form the nickel(II) thiolato complexes $\mathbf{3}$ and 4. Molecular structure of $\mathbf{3}$ confirmed that $\mathbf{L 1}$ and $\mathbf{L 2}$ bind to the nickel atom in a bidentate fashion. Complexes 1-4 catalyzed the Heck coupling reaction of iodobenzene and bromobenzene with methyl acrylate.
\end{abstract}

Keywords: imino-pyridyl; nickel complexes; crystal structure; Heck coupling reactions

\section{1.o Introduction}

The Heck coupling reaction has developed into a very powerful and efficient method of carbon-carbon - bond formation in synthetic organic chemistry both in academic and industry [1]. Historically, palladium complexes of phosphine-based ligands have been extensively used as catalysts in Heck coupling reactions [2]. However, these palladium catalysts have several setbacks associated with their air-sensitivity and rapid decomposition. Moreover, phosphine ligands are expensive and difficult to prepare and this coupled with the high cost of palladium metal, limits their industrial appeal. To circumvent these problems, significant research efforts are currently being directed towards design of cheaper and more stable catalysts [3].

The first approach involves replacement of the phosphine ligands with stronger donor ligands to produce more stable Heck coupling catalysts. One type of ligands that is showing promising results in the Heck coupling reactions are multidentate nitrogen donor ligands. The ease of synthesis and lack of air or moisture sensitivity of nitrogen-based palladium complexes make them suitable replacements for the phosphine palladium catalysts. Following reports by Buchmeiser and coworkers [4] that bis(pyrimidine) palladium complexes catalyze Heck coupling reactions of activated aryl bromides and aryl chlorides with styrene, interests in other nitrogen based catalysts is gaining momentum. Another type of nitrogen-donor ligands that are currently under investigation are the imine-compounds, prepared by condensation reactions of aldehydes and a primary amines [5-6].

The second approach to the development of affordable Heck coupling catalysts is to use cheaper metal sources than palladium. Nickel is emerging as a promising 
replacement of palladium since it is less expensive and has been shown to exhibit catalytic activities comparable to the palladium catalysts in Heck coupling reactions [7a-d]. For example, Domin et. al reported the synthesis of sterically hindered $\alpha$ diimine ligands nickel(II) complexes and their application as Heck coupling reactions of aryl bromide and methyl acrylate [7c]. In this work, we report the synthesis and characterization of new imino-pyridyl nickel(II) complexes and their application as Heck coupling catalysts of aryl halides and methyl acrylate.

\section{Experimental}

\subsection{Materials and methods}

All reactions were carried out under nitrogen atmosphere using standard Schlenk techniques. Solvents were dried and purified by heating at reflux under nitrogen in the presence of a suitable drying agent. All the reagents and starting materials were purchased from Sigma Aldrich and used without any further purification. [NiBr 2 (DME)] (DME = 1,2-dimethoxyethane) was prepared following literature procedure [8]. The imino-pyridyl ligands, (2-pyridyl-2-thiophenemethyl)imine (L1) and (2-pyridyl-2-thiopheneethyl)imine (L2) were synthesized following our published method [9]. ${ }^{1} \mathrm{H}$ NMR experiments were performed on a Varian XR20O $\mathrm{MHz}$ spectrometer. IR spectra in solution were recorded on a Perkin-Elmer Spectrum 100 Series FT-IR instrument using nujol mulls on NaCl plates. Elemental analyses were performed on Server 1112 Series Elemental Analyzer. Magnetic susceptibility measurements were determined at room temperature on EG\&G model155 magnetometer. GC analyses were performed on an Aligient 7689 Series II flameionisation gas chromatograph. Single-crystal X-ray diffraction data was collected on a Bruker KAPPA APEX II DUO diffractometer using graphite-monochromated Mo$\mathrm{K} \alpha$ radiation $(\chi=0.71073 \AA)$. The crystal structure was solved by direct methods using SHELXS-97 [10] and refined by full-matrix least-squares methods based on F using SHELXL-97 [10] and the graphics interface program X-Seed [11-12].

\subsection{Synthesis of the nickel(II) complexes}

2.2.1. Dibromo-[(2-pyridyl-2-thiophenemethyl)imine]nickel (II) (1)

To a solution of $\mathbf{L 1}(0.15 \mathrm{~g}, 0.70 \mathrm{mmol})$ in $\mathrm{CH}_{2} \mathrm{Cl}_{2}(2 \mathrm{ml})$ was added dropwise a solution of $\mathrm{NiBr}_{2}(\mathrm{DME})(0.20 \mathrm{~g}, 0.70 \mathrm{mmol})$ in $\mathrm{CH}_{2} \mathrm{Cl}_{2}(15 \mathrm{ml})$. The reaction was allowed to proceed under reflux for $6 \mathrm{~h}$, resulting in the formation of a light green precipitate. The precipitate was filtered and dried under reduced pressure to give a light green solid. Yield: $0.2466 \mathrm{~g}\left(88 \%\right.$ ), mp: $178^{\circ} \mathrm{C}$, IR (nujol cm$\left.{ }^{-1}\right) ; \mathrm{v}(\mathrm{C}=\mathrm{N})$ 1598, $(\mathrm{C}=\mathrm{C}) 1565,1530,(\mathrm{C}-\mathrm{S}-\mathrm{C})$ 1303. $\mu_{\text {eff, }} 3.18 \mathrm{BM}$. Anal. Calcd for $\mathrm{C}_{11} \mathrm{H}_{10} \mathrm{Br}_{2} \mathrm{~N}_{2} \mathrm{NiS}: \mathrm{C}$, 31.40 ; H, 2.40; N, 6.66; Found: C, 31.11; H, 2.77; N, 7.03

\subsubsection{Dibromo-[(2-pyridyl-2-thiopheneethyl)imine]nickel (II) (2)}

This complex was prepared the same way as in $\mathbf{1}$ using $\mathrm{NiBr}_{2}$ (DME) (0.05 g, 0.15 $\mathrm{mmol}$ ) and $\mathbf{L 2}$ (0.04 g, $0.15 \mathrm{mmol})$. A light green solid was obtained. Yield: $0.05 \mathrm{~g}$ (80 \%), mp: $176^{\circ} \mathrm{C}$. IR (nujol cm-1); v(C=N) 1599, (C=C) 1566, 1528, (C-S-C) 1301. 


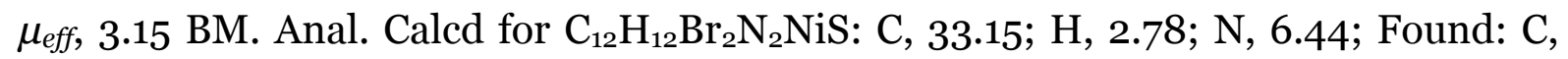
32.93; H, 3.06; N, 6.12

\subsection{3. [(2-pyridyl-2-thiophenemethyl)imine]nickel (II) thiolate (3)}

To a solution of $\mathbf{1}(0.07 \mathrm{~g}, 0.18 \mathrm{mmol})$ in $\mathrm{CH}_{2} \mathrm{Cl}_{2}(15 \mathrm{ml})$ in a Schlenk tube was added 2-hydroxythiophenol (0.023 g, $0.18 \mathrm{mmol}$ ). To this mixture, triethylamine ( $0.4 \mathrm{ml}$, $0.20 \mathrm{mmol}$ ) was added dropwise to give a purple solution. The reaction was allowed to proceed at room temperature for $4 \mathrm{~h}$. The purple solution was concentrated to about $10 \mathrm{ml}$ before excess hexane was added to give a purple precipitate. The precipitate was filtered and dried under reduced pressure to obtain a grey solid. Recrystallization from $\mathrm{CH}_{2} \mathrm{Cl}_{2}$ /hexane mixture afforded purple crystals suitable for single X-ray crystallography analysis. Yield: $0.0617 \mathrm{~g}$ (90\%). mp: $184{ }^{\circ} \mathrm{C} .{ }^{1} \mathrm{H}$ NMR (200 $\left.\mathrm{MHz} \mathrm{CDCl}_{3}\right) \delta 3.04\left(\mathrm{~s}, 2 \mathrm{H},-\mathrm{CH}_{2}\right) ; 6.79\left(\mathrm{~d}, 1 \mathrm{H}, 3 J_{H H}=5.0 \mathrm{~Hz}\right.$, phenyl); $6.83(\mathrm{t}$, $1 \mathrm{H}, 3 J_{H H}=4.8 \mathrm{~Hz}$, thiophen); $6.86\left(\mathrm{~d}, 1 \mathrm{H}, 3 J_{H H}=5.4 \mathrm{~Hz}\right.$, phenyl); $6.92\left(\mathrm{t}, 2 \mathrm{H}, 3 J_{\mathrm{HH}}=\right.$ $4.8 \mathrm{~Hz}$, phenyl); $6.98\left(\mathrm{t}, 2 \mathrm{H}, 3 J_{\mathrm{HH}}=4.4 \mathrm{~Hz}, \mathrm{py}\right) ; 7.02\left(\mathrm{~d}, 1 \mathrm{H}, 3 J_{H H}=5.2 \mathrm{~Hz}, \mathrm{py}\right) ; 7.20$ $\left(\mathrm{d}, 1 \mathrm{H}, 3 J_{\mathrm{HH}}=4.8 \mathrm{~Hz}\right.$, thiophen); $7.38(\mathrm{~s}, 1 \mathrm{H},-\mathrm{CH}=\mathrm{N}) ; 7.40\left(\mathrm{~d}, 1 \mathrm{H}, 3 J_{\mathrm{HH}}=5.2 \mathrm{~Hz}\right.$, thiphene); $7.44\left(\mathrm{~d}, 1 \mathrm{H}, 3 J_{H H}=4.8 \mathrm{~Hz}\right.$, py). IR (nujol $\left.\mathrm{cm}^{-1}\right) ; \mathrm{v}(\mathrm{C}=\mathrm{N})$ 1592, $(\mathrm{C}=\mathrm{C}) 1560$, 1532, (C-S-C) 1307. Anal. Calcd for $\mathrm{C}_{17} \mathrm{H}_{14} \mathrm{~N}_{2} \mathrm{NiOS}_{2}$ : C, 53.02; H, 3.66; N, 7.27; Found: C, 53.18; H, 3.88; N, 7.46

\subsection{4. [(2-pyridyl-2-thiopheneethyl)imine]nickel (II) thiolate (4)}

The complex was prepared the same way as in $\mathbf{3}$ using 2-hydroxythiophenol (0.03 $\mathrm{g}$, $0.20 \mathrm{mmol}$ ) and 2 (0.10 g, $0.20 \mathrm{mmol}$ ). Yield: $0.08 \mathrm{~g}$ (92 \%). mp: $181{ }^{\circ} \mathrm{C} .{ }^{1} \mathrm{H} \mathrm{NMR}$ $\left(200 \mathrm{MHz} \mathrm{CDCl}_{3}\right) \delta 3.08\left(\mathrm{t}, 2 \mathrm{H}, 3 J_{H H}=4.6 \mathrm{~Hz},=\mathrm{N}-\mathrm{CH}_{2}\right) ; 3.55\left(\mathrm{t}, 2 \mathrm{H}, 3 J_{H H}=4.6 \mathrm{~Hz}\right.$, $\left.-\mathrm{CH}_{2}\right) ; 6.46\left(\mathrm{t}, 2 \mathrm{H}, 3 J_{H H}=4.8 \mathrm{~Hz}\right.$, phenyl). $6.59\left(\mathrm{~d}, 2 \mathrm{H}, 3 J_{H H}=4.4 \mathrm{~Hz}\right.$, phenyl); 6.74 $\left(\mathrm{d}, 1 \mathrm{H}, 3 J_{H H}=4.8 \mathrm{~Hz}\right.$, thiophen); $6.87\left(\mathrm{t}, 2 \mathrm{H}, 3 J_{H H}=4.2 \mathrm{~Hz}, \mathrm{py}\right) ; 7.17\left(\mathrm{t}, 1 \mathrm{H},{ }^{3} J_{H H}=\right.$ $4.2 \mathrm{~Hz}$, thiophen); $7.24\left(\mathrm{~d}, 1 \mathrm{H}, 3 J_{H H}=4.8 \mathrm{~Hz}, \mathrm{py}\right) ; 7.30\left(\mathrm{~d}, 1 \mathrm{H}, 3 J_{\mathrm{HH}}=4.4 \mathrm{~Hz}\right.$, thiophene); $7.35(\mathrm{~s}, 1 \mathrm{H},-\mathrm{CH}=\mathrm{N}) ; 7.39\left(\mathrm{~d}, 1 \mathrm{H}, 3 J_{H H}=4.8 \mathrm{~Hz}, \mathrm{py}\right) ; \mathrm{IR}\left(\right.$ nujol cm $\left.\mathrm{cm}^{-1}\right)$; $v(C=N)$ 1593, $(C=C)$ 1561, 1533, $(\mathrm{C}-\mathrm{S}-\mathrm{C})$ 1305. Anal. Calcd for $\mathrm{C}_{18} \mathrm{H}_{16} \mathrm{~N}_{2} \mathrm{NiOS}_{2}$ : C, 54.16; H, 4.04; N, 7.02; Found: C, 53.98; H, 3.88; N, 7.23.

\subsection{Heck coupling catalysis}

In a typical reaction, a dry $100 \mathrm{ml}$ Schlenk tube equipped with a magnetic bar was charged with iodobenzene ( $2.04 \mathrm{~g}, 0.01 \mathrm{~mol})$, methyl acrylate $(1.03 \mathrm{~g}, 0.01 \mathrm{~mol})$ and triethylamine $(1.00 \mathrm{~g}, 0.01 \mathrm{~mol})$. The respective nickel complex $(0.01 \mathrm{mmol})$ was dissolved in $10 \mathrm{ml}$ DMF and transferred to the Schlenk tube and the temperature was set at $80{ }^{\circ} \mathrm{C}$. Samples were drawn at regular intervals and analyzed by GC to determine the percentage conversions. The coupling product was isolated by the addition of water $(5 \mathrm{O} \mathrm{ml})$ to the reaction mixture and extracted with $\mathrm{CH}_{2} \mathrm{Cl}_{2}$ to give the product which was analyzed by ${ }^{1} \mathrm{H}$ NMR spectroscopy. Homogeneity tests were performed using mercury drop experiments in duplicate by adding two drops of elemental mercury to the reaction described above. After the reaction period, the solution was filtered and analyzed by GC and ${ }^{1} \mathrm{H}$ NMR. 


\section{Results and discussion}

3.1. Synthesis and characterization of the nickel complexes

The imino-pyridyl ligands, L1 and L2, were prepared following our published method [9]. Reactions of $\mathbf{L 1}$ and $\mathbf{L} \mathbf{2}$ with $\mathrm{NiBr}_{2}$ (DME) afforded the corresponding complexes $\mathbf{1}$ and $\mathbf{2}$ in high yields (Scheme 1). In attempts to improve the solubility of the resultant compounds, complexes $\mathbf{1}$ and $\mathbf{2}$ were reacted with equivalent amounts of 2-hyroxythiophenol to give complexes $\mathbf{3}$ and $\mathbf{4}$ respectively (Scheme 1). All the isolated complexes (1-4) were characterized using micro-elemental analyses, IR spectroscopy, magnetic moment measurements for $\mathbf{1}$ and $\mathbf{2}$ and single crystal X-ray crystallography for $\mathbf{3}$. The elemental analyses data obtained were consistent with the proposed structures shown in Scheme 1 and confirmed the purity of the compounds. The IR spectra of the complexes showed absorption bands between $1592 \mathrm{~cm}^{-1}-1598$ $\mathrm{cm}^{-1}$; which is typical of coordinated imines [9 and 13]. Magnetic susceptibility measurements for $\mathbf{1}$ and $\mathbf{2}$ were obtained as 3.18 and $3.15 \mathrm{BM}$, consistent with two unpaired electrons for high spin nickel(II) complexes in a tetrahedral environment [14]. On the other hand, complexes $\mathbf{3}$ and $\mathbf{4}$ were diamagnetic in agreement with square planar nickel(II) complexes as confirmed by the solid state structure of $\mathbf{3}$.

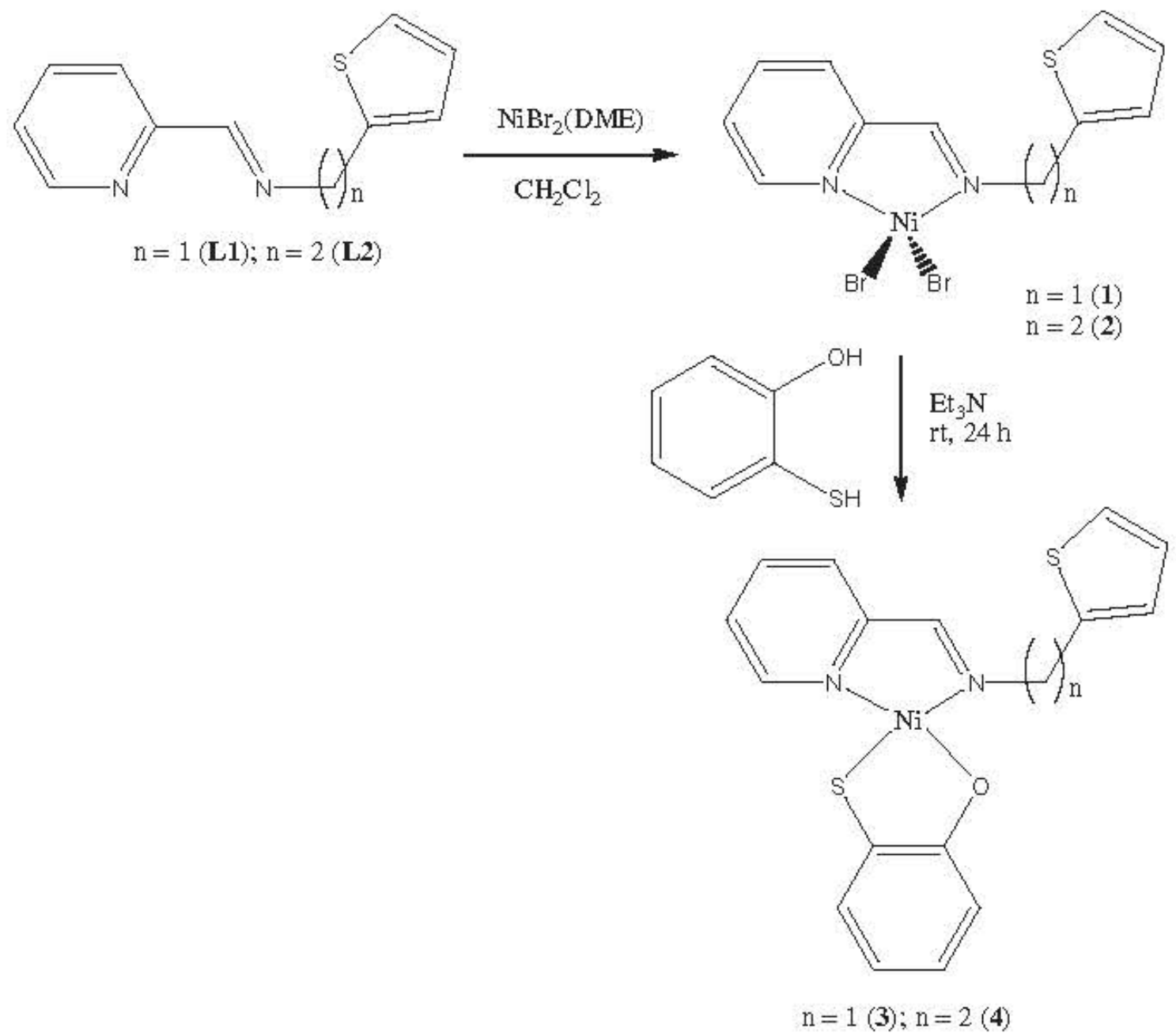

Scheme 1: Preparation of imino-pyridyl nickel (II) complexes 1-4 


\subsection{Molecular structure of complex $\mathbf{3}$}

Single crystals of $\mathbf{3}$ were grown by slow diffusion of hexane into a dichloromethane solution at $4{ }^{\circ} \mathrm{C}$. Crystal data and structure refinement parameters are summarized in Table 1, while selected bond lengths and angles are given in Table 2. The molecular structure of $\mathbf{3}$ is shown in Figure 1. The complex crystallizes with one molecule in the asymmetric unit in the $P 21 / \mathrm{m}$ space group. Apart from the disordered thiophene ring [with occupancies of $0.535(6)$ and $0.465(6)$ ], the rest of the atoms in the molecule all lie in this plane of symmetry which is parallel to the (o 1 o) plane. The plane of the thiophene ring is at a dihedral angle of $81.9(2)^{\circ}$ from the plane on which the bulk of the molecule is residing.

Ligand L1 coordinates to the nickel metal ion via the pyridyl and imine nitrogen atoms while the thiophenyl sulfur atom is uncoordinated. The hydroxythiophenyl ligand loses two hydrogen atoms to become bidentate and coordinates to the metal ion through the phenylthiolate-S and the phenoxy-O to complete a slightly distorted square planar geometry around the metal centre. The angles around the nickel centre of 83.51(12), 89.96(11), 90.44(7) and $96.09(8)^{\circ}$ are close to related nickel (II) thiolate compounds [15]. This is common for similar hetero donor atom nickel complexes. The Ni- $\mathrm{N}_{\text {imine }}$ and $\mathrm{Ni}-\mathrm{N}_{\text {pyridyl }}$ bond distances are 1.897(3) and 1.919(3) respectively while the Ni-S and Ni-O bond distances are 2.1612(8) and 1.845(2) $\AA$ which are consistent with those reported for related nickel thiolate complexes and Schiff base complexes [17]. 
Table 1: Crystallographic data and refinement for complex $\mathbf{3}$

\begin{tabular}{|c|c|}
\hline Crystallographic data & 3 \\
\hline Empirical formula & $\begin{array}{lllll}\mathrm{C} 17.93 & \mathrm{H} 15 & \mathrm{~N} 2 & \mathrm{Ni} & \mathrm{O} \\
\mathrm{S} 2.07 & & & & \end{array}$ \\
\hline Formula weight & 399.55 \\
\hline Temperature (K) & $100(2) \mathrm{K}$ \\
\hline Wavelength & $0.71069 \AA$ \\
\hline Crystal system & Monoclinic \\
\hline Space group & $P 2_{1} / m$ \\
\hline Unit cell dimensions & \\
\hline$a(\AA)$ & $10.0387(9) \AA$ \\
\hline$b(\AA)$ & $6.6952(6) \AA$ \\
\hline$c(\AA)$ & $12.6824(11) \AA$ \\
\hline$\beta\left(^{\circ}\right)$ & $102.769(2)^{\circ}$ \\
\hline$V\left(\AA^{3}\right)$ & 831.32(13) A3 \\
\hline $\mathrm{Z}$ & 2 \\
\hline $\mathrm{D}_{\text {cal }}\left(\mathrm{Mgm}^{-3}\right)$ & $1.596 \mathrm{Mg} / \mathrm{m} 3$ \\
\hline Absorption coefficient $\left(\mathrm{mm}^{-1}\right)$ & $1.434 \mathrm{~mm}^{-1}$ \\
\hline $\mathrm{F}($ ооо $)$ & 411 \\
\hline Crystal size (mm3) & $0.31 \times 0.04 \times 0.03 \mathrm{~mm} 3$ \\
\hline Final R indices (R1) & 0.0370 \\
\hline $\mathrm{R}$ indices all data ( $\mathrm{R} 1)$ & 0.0541 \\
\hline Completeness to theta & $99.6 \%$ \\
\hline Goodness-of-fit on $\mathrm{F}^{2}$ & 1.023 \\
\hline Largest diff. peak and hole & 0.749 and -0.418 e. $\AA-3$ \\
\hline
\end{tabular}

Table 2: Selected bond lengths and bond angles for complex $\mathbf{3}$

\begin{tabular}{|c|c|c|c|c|}
\hline Complex & \multicolumn{2}{|c|}{ Bond length ( $(\AA)$} & \multicolumn{2}{|c|}{ Bond angle $\left(^{\circ}\right)$} \\
\hline \multirow[t]{9}{*}{3} & $\mathrm{Ni}(1)-\mathrm{N}(1)$ & $1.919(3)$ & $\mathrm{N}(1)-\mathrm{Ni}(1)-\mathrm{N}(2)$ & $83.55(12)$ \\
\hline & $\mathrm{Ni}(1)-\mathrm{N}(2)$ & $1.897(3)$ & $\mathrm{O}(1)-\mathrm{Ni}(1)-\mathrm{S}(2)$ & $90.45(7)$ \\
\hline & $\mathrm{Ni}(1)-\mathrm{O}(1)$ & $1.845(2)$ & $\mathrm{O}(1)-\mathrm{Ni}(1)-\mathrm{N}(1)$ & $89.94(11)$ \\
\hline & $\mathrm{Ni}(1)$ & $S(2)$ & $\mathrm{S}(2)-\mathrm{Ni}(1)-\mathrm{N}(2)$ & $96.06(8)$ \\
\hline & $2.1614(8)$ & & $C(12)-S(2)-N i(1)$ & $96.70(11)$ \\
\hline & $N(1)-C(1)$ & $1.342(4)$ & $\mathrm{C}(11)-\mathrm{O}(1)-\mathrm{Ni}(1)$ & $117.8(2)$ \\
\hline & $N(1)-C(5)$ & $1.343(4)$ & $\mathrm{Ni}(1)-\mathrm{N}(2)-\mathrm{C}(7)$ & $124 \cdot 5(2)$ \\
\hline & $N(2)-C(6)$ & $1.295(4)$ & $N(2)-C(7)-C(8)$ & 116.1(3) \\
\hline & $\mathrm{N}(2)-\mathrm{C}(7)$ & $1.472(4)$ & & \\
\hline
\end{tabular}




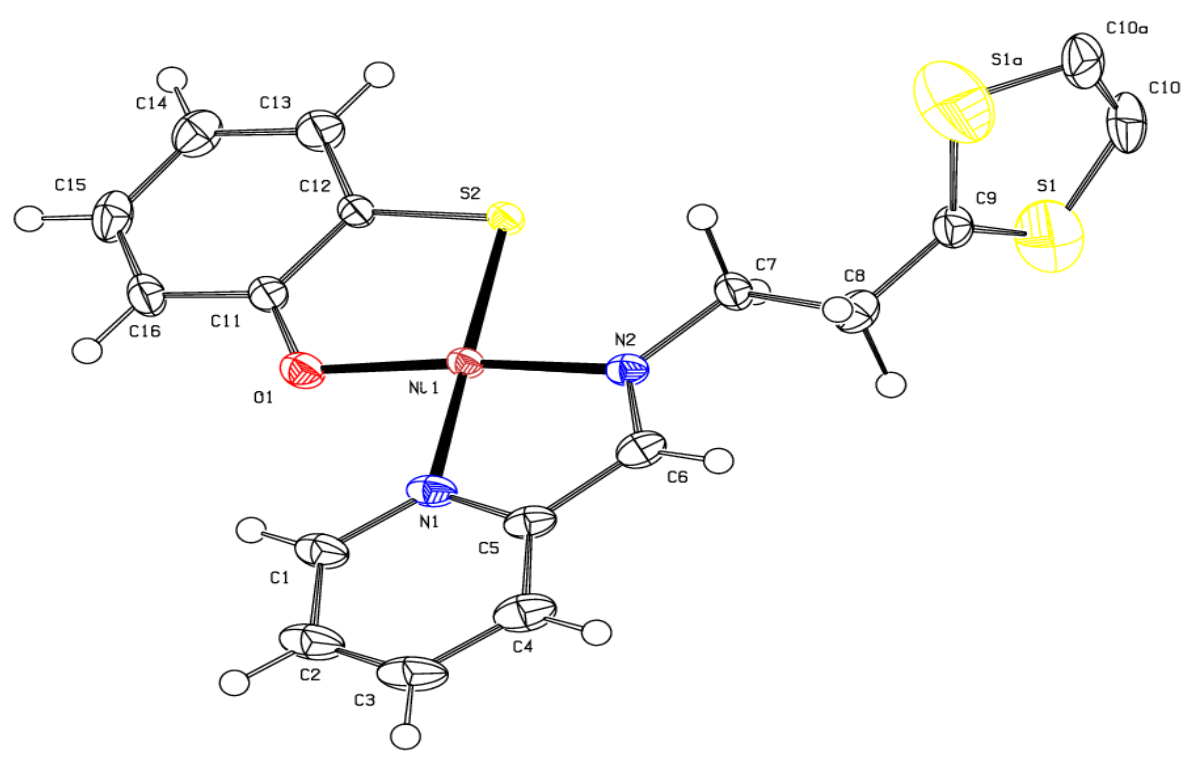

Fig. 1 X-ray crystal structure of $\mathbf{3}$.

\subsection{Heck coupling reactions}

The nickel complexes, $\mathbf{1 - 4}$, were investigated as catalysts in the model Heck coupling reaction of iodobenzene, bromobenzene and chlorobenzene with methyl acrylate (Eq. (1)). This was performed in order to evaluate the catalytic activities of these nickel complexes in Heck coupling reactions relative to the well established palladium complexes. All the complexes efficiently catalyzed the coupling of iodobenzene with methyl acrylate (Table

3). Most significant is the abilities of $\mathbf{1}-\mathbf{4}$ to catalyze this reaction at temperatures of $80{ }^{\circ} \mathrm{C}$, considered very mild for Heck reactions even for palladium catalysts. Generally, complexes 1 and 2 showed better catalytic activities than 3 and 4 under similar conditions (Table 3, entries 1 and 2 versus 3 and 4). Increasing the reaction temperature from 80 to $110{ }^{\circ} \mathrm{C}$ resulted in a concurrent increase in percent conversion of the complexes. For instance, complex 1 gave conversions of $80 \%$ and $88 \%$ in $4 \mathrm{~h}$ at 80 and $110^{\circ} \mathrm{C}$, respectively (Table 3, entries 1 and 11). However, increasing the temperature from $110{ }^{\circ} \mathrm{C}(88 \%)$ to $130{ }^{\circ} \mathrm{C}(89 \%)$ did not result in significant increase in activity (Table 3 , entries 11 and 12). It is generally believed that in the Heck coupling reaction, Ni(II) species may be reduced to ligand-stabilized $\mathrm{Ni}(\mathrm{O})$ via a Pd(II) related mechanism [18]. Mercury drop experiments showed no significant differences in conversion between the experiments with or without mercury (Table 3, entry 7 and 9), therefore suggesting that no heterogeneous $\mathrm{Ni}(\mathrm{o})$ was involved in the catalytic process. It is therefore conceivable that the improved catalytic activities observed at higher temperatures could be due to enhanced reduction of complexes $\mathbf{1}-\mathbf{4}$ to ligand stabilized nickel (o). 
Table 3: Heck coupling reactions of iodobenzene with methyl acrylate catalyzed by complexes 1-4

\begin{tabular}{|l|l|l|l|l|}
\hline Entry & Catalyst & Temp (oC) & Time (h) & Conversion\% $^{\mathbf{b}}$ \\
\hline 1 & $\mathbf{1}$ & 80 & 4 & 80 \\
\hline 2 & $\mathbf{2}$ & 80 & 4 & 85 \\
\hline 3 & $\mathbf{3}$ & 80 & 4 & 54 \\
\hline 4 & $\mathbf{4}$ & 80 & 4 & 62 \\
\hline 5 & $\mathbf{1}$ & 80 & 8 & 85 \\
\hline 6 & $\mathbf{2}$ & 80 & 8 & 89 \\
\hline $7^{\mathrm{c}}$ & $\mathbf{2}$ & 80 & 8 & 88 \\
\hline 8 & $\mathbf{3}$ & 80 & 24 & 75 \\
\hline $9^{\mathrm{c}}$ & $\mathbf{3}$ & 80 & 24 & 75 \\
\hline 10 & $\mathbf{4}$ & 80 & 24 & 78 \\
\hline 11 & $\mathbf{1}$ & 110 & 4 & 88 \\
\hline 12 & $\mathbf{1}$ & 130 & 4 & 89 \\
\hline 13 & $\mathbf{4}$ & 130 & 4 & 63 \\
\hline 14 & $\mathbf{4}$ & 130 & 24 & 83 \\
\hline $15^{\mathrm{d}}$ & $\mathbf{1}$ & 130 & 8 & 0 \\
\hline $16^{\mathrm{d}}$ & $\mathbf{1}$ & 130 & 24 & 23 \\
\hline $17^{\mathrm{e}}$ & $\mathbf{1}$ & 130 & 24 & 0 \\
\hline
\end{tabular}

aReaction conditions: $\mathrm{Ni}(0.01 \mathrm{mmol}) ; \mathrm{PhI}(10 \mathrm{mmol})$; methyl acrylate (10 mmol); $\mathrm{Et}_{3} \mathrm{~N}$ (10 mmol); solvent: DMF (10 ml).

bDetermined by GC using mesitylene as the internal standard;

cMercury drop test;

dBromobenzene;

eChlorobenzene.

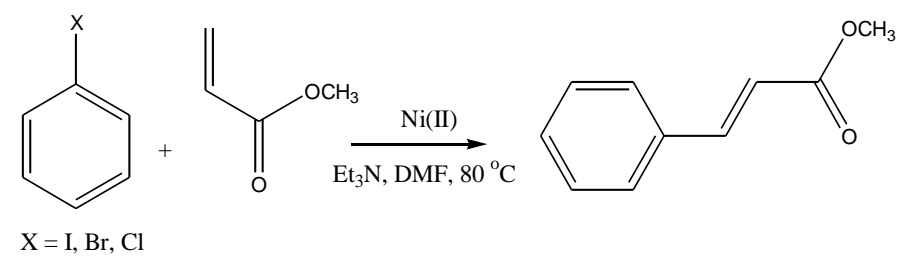

(1)

Complexes 1 and 2 exhibited shorter induction periods than 3 and 4. For instance, while the dibromide complexes, $\mathbf{1}$ and $\mathbf{2}$, gave conversions of $80 \%$ and $85 \%$ in $4 \mathrm{~h}$, respectively, the thiolate analogs, $\mathbf{3}$ and $\mathbf{4}$, only gave conversions of $54 \%$ and $66 \%$, respectively (Table 3, entries 1-4). The slower conversion rates observed in 3 and 4 could thus be attributed to their increased stabilities emanating from the chelating effect of the thiolato ligand [18]. The

melting point data of complexes $\mathbf{1}-\mathbf{4}$ is in good agreement with this trend, complexes $3\left(184^{\circ} \mathrm{C}\right)$ and $4\left(181^{\circ} \mathrm{C}\right)$ gave higher melting points than $1\left(178{ }^{\circ} \mathrm{C}\right)$ and $2\left(176^{\circ} \mathrm{C}\right)$. The chain length of the alkyl linker in 1-4 also appeared to have some influence on the activities of the resultant catalysts. For instance, while catalyst 1 (methyl linker) 
gave conversion of 80\%, the analogs catalyst 2 (ethyl linker) gave $85 \%$ under similar conditions (Table 3, entries 1 and 2). Similar trend was observed for $\mathbf{3}$ and $\mathbf{4}$ (Table 3 , entries 3 and 4). This behavior could be due to the flexibility of the ethyl linker which might reduce the stabilizing role of the thiophene group. In all cases, transmethyl cinnamate was obtained as the predominant product as established by $1 \mathrm{H}$ NMR spectroscopy. The ultimate objective in designing Heck coupling catalyst is to form active species that can catalyze the coupling of the more difficult aryl bromides and chlorides. We thus investigated the most active complex $\mathbf{1}$ in the coupling of methyl acrylate with bromobenzene and chlorobenzene. The reactions were carried at $130{ }^{\circ} \mathrm{C}$ for 8 and $24 \mathrm{~h}$. No catalytic activity was observed within $8 \mathrm{~h}$ with bromobenzene, but after $24 \mathrm{~h}$, substrate conversion of $23 \%$ was reported. However, no catalytic activity was observed in the coupling reactions of chlorobenzene with methyl acrylate even after $24 \mathrm{~h}$ and at elevated temperatures of $130{ }^{\circ} \mathrm{C}$. This trend is consistent with the increasing strength of carbon-halide bonds from aryl iodide to aryl chloride [1c].

\section{Conclusions}

We have successfully prepared new nickel(II) complexes containing imino-pyridyl derived ligands. These complexes were evaluated as catalysts for Heck reactions of aryl halides with methyl acrylate and displayed good catalytic activities under mild conditions towards iodobenzene and bromobenzene. Thus these nickel(II) complexes could offer more stable alternative catalysts to the established phoshine-based palladium catalysts.

\section{Acknowledgements}

The authors thank University of the Western Cape, National Research Foundation (NRF, South Africa) and Botswana Government for financial support.

\section{Supplementary material}

CCDC no. 837633 contains the supplementary crystallographic data for compound $\mathbf{3}$. Copies of this information may be obtained free of charge from The Director, CCDC, 12 Union Road, Cambridge, CB2 1EZ, UK (fax: +44-1223-336033; e-mail: deposit@ccdc.cam.ac.uk or www: http://www.ccdc.cam.ac.uk). 


\section{References}

[1] (a) T. Mizoroki, K. Mori, A. Ozaki, Bull. Chem. Soc. Jpn. 44 (1971) 581.

(b) R. F. Heck, J. P. Nolley, J. Org. Chem. 37 (1972) 2320.

(c) N. J. Whitcombe, K. K. (mimi) Hii, S. E. Gibson, Tetrahedron 57 (2001) 7447.

(d) T. Welton, Chem. Rev. 99 (1999) 2071.

(e) G. Schmidt, Chem. Rev. 92 (1992) 1709.

(f) C. Wu, US Patent 5536870 (1996).

(g) P. Baumeister, G. Seifert, H. Steiner, EP Patent 584043 A1 (1994).

(h) R. A. Devries, H. R. Frick, US Patent 5136069 (1992).

[2] (a) A. M. Trzeciak, J. J. Ziolkowaski, Coord. Chem. Rev. 249 (2005) 2308.

(b) C. J. Elsevier, Coord. Chem. Rev. 185 (1999) 809.

(c) G. T. Crisp, Chem. Rev. 27 (1998) 427.

[3] (a) V. V. Grushin, H. Alper, Chem. Rev. 94 (1994) 1047.

(b) C. Rocoboy, J. A. Gladysz, Org. Lett. 4 (2002) 1993.

(c) M. Feuerstein, H. Doucet, M. Santelli, J. Org. Chem. 66 (2001) 5923.

(d) A. M. Hollas, W. Gu, N. Bhuvanesh, O. V. Ozerov, Inorg. Chem. 50 (2011),3673.

(e) F. Korad, J. L. Fillol, H. Wadepohl, L. H. Gade Inorg. Chem. 48 (2009) 8523.

(f) J. L. Cryder, A. J. Killgore, C. Moore, J. A. Collen, A. L. Rheingold, C. J. Darley, Dalton Trans. 39 (2010) 10671.

[4] M. R. Buchmeiser, T. Schareina, R. Kempe, K. Wurst, J. Organomet. Chem. 634 (2007) 39.

[5] K. C. Gupta, A. K. Sutat, Coord. Chem. Rev. 253 (2007) 1420 and references therein.

[6] X. Guo, J. Zhou, X. Li, H. Sun, J. Organomet. Chem. 693 (2008) 3692.

[7] (a) S. Ma, H. Wang, K. Gao, F. Zhao, J. Mol. Catal. A: Chem. 248 (2006) 17.

(b) R. Matsubara, A. C. Gutierrez, T. F. Jamison, J. Am. Chem. Soc. 133 (2011) 19020.

(c) D. Domin, D. B-Garagorri, K. Mereiter, J. Fro“hlich, K. Kirchner, Organometallics 24 (2005) 3957.

(d) B-L. Lin, L. Liu, Y. Fu, S-W. Luo, Q. Chen, Q-Xi. Guo, Organometallics 23 (2004) 2114

[8] L.G.L. Ward, Inorg. Synth. 13 (1972) 154.

[9] W.M. Motswainyana, S.O. Ojwach, M.O. Onani, E.I. Iwuoha, J. Darkwa, Polyhedron, 30 (2011) 2574. 
[10] G. M. Sheldrick, SHELXS-97, SHELXL-97 and SADABS version 2.05, University of Göttingen, Germany, 1997.

[11] L. J. Barbour, J. Supramol. Chem. 1 (2001) 189.

[12] J. L. Atwood, L.J. Barbour, Cryst. Growth Des. 3 (2003) 3.

[13] S.M. Nobre, A.L. Monteiro, J. Mol. Catal. A: Chem. 313 (2009) 65.

[14] (a) T.C. Higgs, C.J. Carrano, Inorg. Chem. 36 (1997) 298 (b) Y-B. Huang, W-G. Jia, G-X. Jin, J. Organomet. Chem. 694 (2009) 86.

[15] E. Pereira, L. Gomes, B. de Castro, Inorg. Chim. Acta. 271 (1998) 83.

[16] W. Zhang, W-H. Sun, B. Wu, S. Zhang, H. Ma, Y. Li, J. Cheng, P. Hao, J. Organomet. Chem. 691 (2006) 4759.

[17] (a) T. Yamamura, H. Watanabe, Y. Niino, K. Fujisawa, Y. Morooka, Inorg. Chim. Acta 263 (1997) 415. (b) I.C. Santos, M. Vilas-Boas, M.F.M. Piedade, C. Freire, M.T. Duarte, B. de Castro, Polyhedron 19 (2000) 655.

[18] J. G. de Vries, Dalton Trans. (2006) 421. 


\section{Table captions}

Table 1: Crystallographic data and structure refinement parameters for complex 3.

Table 2: Selected bond lengths and bond angles for complex $\mathbf{3}$.

Table 3: Heck coupling reaction of iodobenzene with methyl acrylate catalysed by complexes1-4 ${ }^{\mathrm{a}}$

\section{Figure captions}

Figure 1: Molecular structure of complex 3. There is a disorder in the thiophene ring (hence the large $\mathrm{S}(1)$ and $\mathrm{C}(10)$ thermal ellipsoids). The thiophene is sitting in a special position so only half of it is seen in the asymmetric unit.

\section{Table 1:}

\begin{tabular}{|c|c|}
\hline Crystallographic data & $\mathbf{3}$ \\
\hline Empirical formula & $\begin{array}{lllll}\mathrm{C} 17.93 & \mathrm{H} 15 & \mathrm{~N} 2 & \mathrm{Ni} & \mathrm{O} \\
\mathrm{S} 2.07 & & & & \end{array}$ \\
\hline Formula weight & 399.55 \\
\hline Temperature (K) & $100(2) \mathrm{K}$ \\
\hline Wavelength & $0.71069 \AA$ \\
\hline Crystal system & Monoclinic \\
\hline Space group & $P 2_{1} / m$ \\
\hline Unit cell dimensions & \\
\hline$A(\AA)$ & $10.0387(9) \AA$ \\
\hline$B(\AA)$ & $6.6952(6) \AA$ \\
\hline$C(\AA)$ & $12.6824(11) \AA$ \\
\hline $\mathrm{B}\left({ }^{\circ}\right)$ & $102.769(2)^{\circ}$ \\
\hline $\mathrm{V}\left(\AA^{\AA} 3\right)$ & 831.32(13) ̊̊3 \\
\hline $\mathrm{Z}$ & 2 \\
\hline $\mathrm{D}_{\text {cal }}\left(\mathrm{Mgm}^{-3}\right)$ & $1.596 \mathrm{Mg} / \mathrm{m} 3$ \\
\hline Absorption coefficient $\left(\mathrm{mm}^{-1}\right)$ & $1.434 \mathrm{~mm}^{-1}$ \\
\hline $\mathrm{F}($ оoо $)$ & 411 \\
\hline Crystal size $\left(\mathrm{mm}^{3}\right)$ & $0.31 \times 0.04 \times 0.03 \mathrm{~mm} 3$ \\
\hline Final R indices (R1) & 0.0368 \\
\hline $\mathrm{R}$ indices all data (R1) & 0.0538 \\
\hline Completeness to theta & $99.6 \%$ \\
\hline Goodness-of-fit on $\mathrm{F}^{2}$ & 1.022 \\
\hline Largest diff. peak and hole & 0.7509 and -0.400 e. $\AA^{-3}$ \\
\hline
\end{tabular}


Table 2:

\begin{tabular}{|lrlr|}
\hline \multicolumn{2}{|c|}{ Bond length ( $\AA$ ) } & \multicolumn{2}{c|}{ Bond angle (') } \\
\hline $\mathrm{Ni}(1)-\mathrm{N}(1)$ & $1.919(3)$ & $\mathrm{N}(1)-\mathrm{Ni}(1)-\mathrm{N}(2)$ & $83.51(12)$ \\
$\mathrm{Ni}(1)-\mathrm{N}(2)$ & $1.897(3)$ & $\mathrm{O}(1)-\mathrm{Ni}(1)-\mathrm{S}(2)$ & $90.44(7)$ \\
$\mathrm{Ni}(1)-\mathrm{O}(1)$ & $1.845(2)$ & $\mathrm{O}(1)-\mathrm{Ni}(1)-\mathrm{N}(1)$ & $89.96(11)$ \\
$\mathrm{Ni}(1)$ & $\mathrm{S}(2)$ & $\mathrm{S}(2)-\mathrm{Ni}(1)-\mathrm{N}(2)$ & $96.69(8)$ \\
$2.1614(8)$ & & & \\
& & & \\
\hline
\end{tabular}

Table 3:

\begin{tabular}{|l|l|l|l|l|}
\hline Entry & Catalyst & Temp ('C) & Time (h) & Conversion\% $^{\mathbf{b}}$ \\
\hline 1 & $\mathbf{1}$ & 80 & 4 & 80 \\
2 & $\mathbf{2}$ & 80 & 4 & 85 \\
3 & $\mathbf{3}$ & 80 & 4 & 54 \\
4 & $\mathbf{4}$ & 80 & 4 & 62 \\
5 & $\mathbf{1}$ & 80 & 8 & 85 \\
6 & $\mathbf{2}$ & 80 & 8 & 89 \\
$7^{\mathrm{c}}$ & $\mathbf{2}$ & 80 & 8 & 88 \\
8 & $\mathbf{3}$ & 80 & 24 & 75 \\
$9^{\mathrm{c}}$ & $\mathbf{3}$ & 80 & 24 & 75 \\
10 & $\mathbf{4}$ & 80 & 24 & 78 \\
11 & $\mathbf{1}$ & 110 & 4 & 88 \\
12 & $\mathbf{1}$ & 130 & 4 & 89 \\
13 & $\mathbf{4}$ & 130 & 4 & 63 \\
14 & $\mathbf{4}$ & 130 & 24 & 83 \\
$15^{\mathrm{d}}$ & $\mathbf{1}$ & 130 & 8 & 0 \\
$16^{\mathrm{d}}$ & $\mathbf{1}$ & 130 & 24 & 23 \\
$17^{\mathrm{e}}$ & $\mathbf{1}$ & 130 & 24 & 0 \\
\hline
\end{tabular}

aReaction conditions: $\mathrm{Ni}(0.01 \mathrm{mmol})$; $\mathrm{PhI}(10 \mathrm{mmol})$; methyl acrylate $(10 \mathrm{mmol})$; $\mathrm{Et}_{3} \mathrm{~N}$ (10 mmol); solvent: DMF (10 ml). b Determined by GC using mesitylene as the internal standard; cMercury drop test; dBromobenzene; ${ }^{\mathrm{e} C h l o r o b e n z e n e . ~}$ 


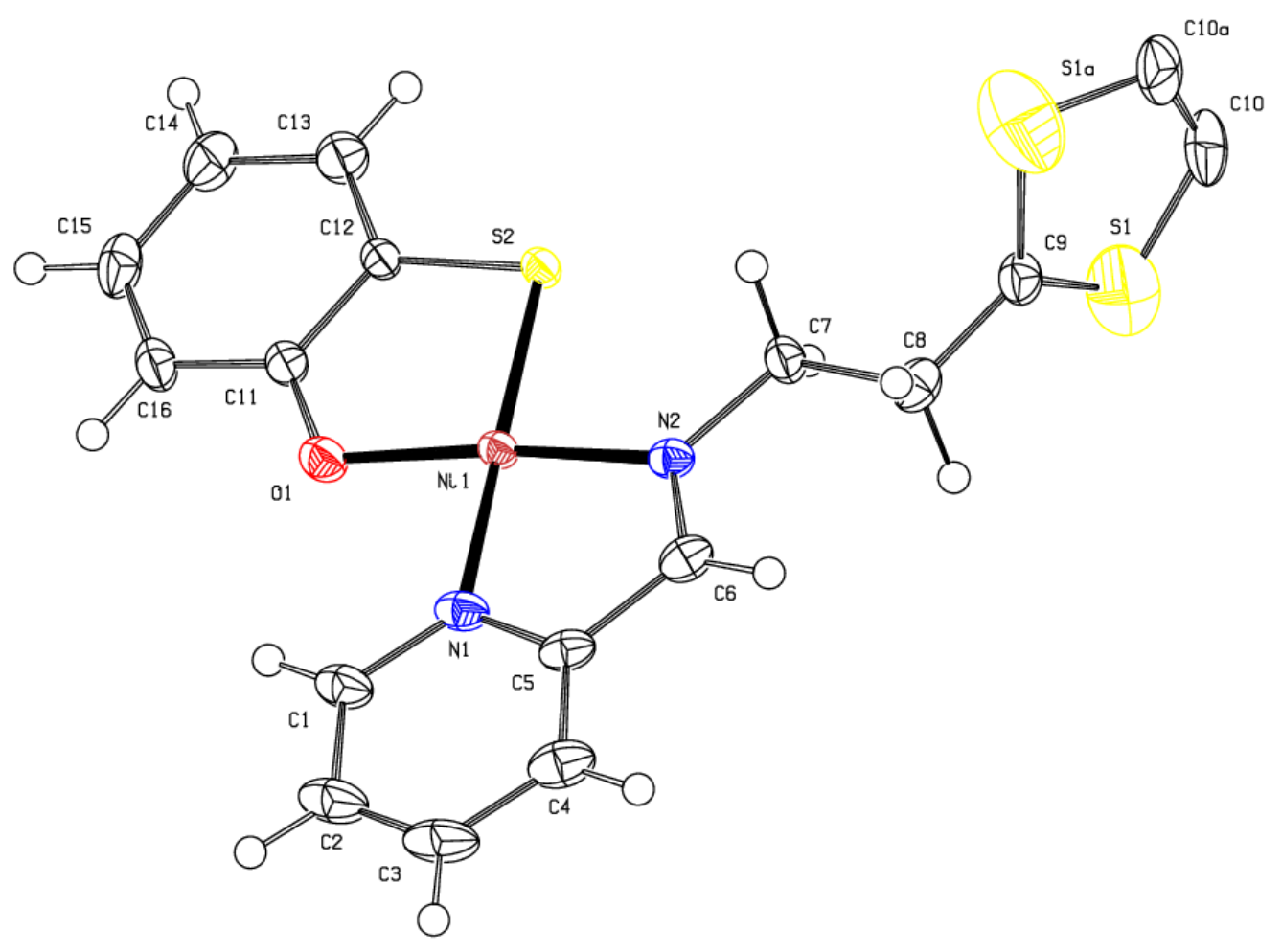

Figure 1.

14 


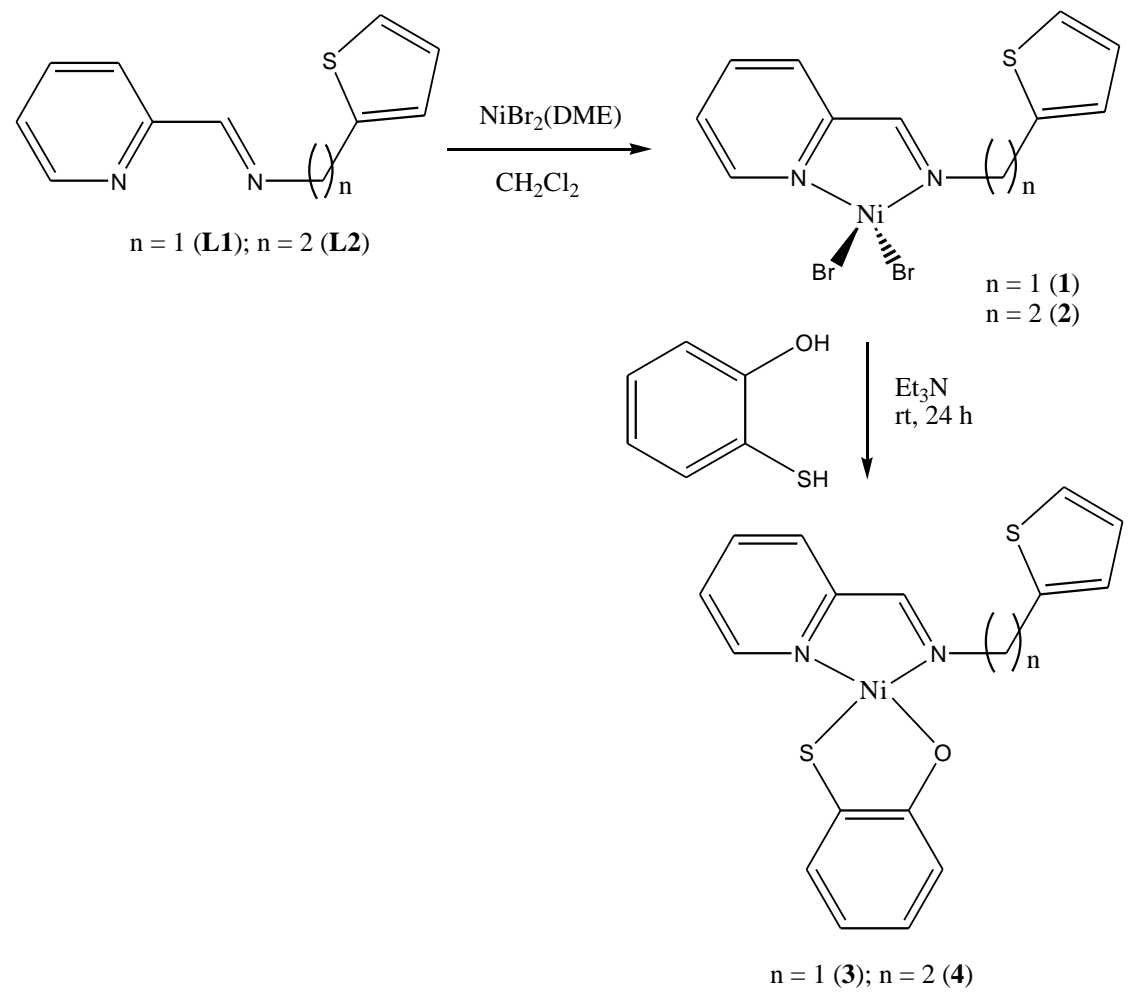

Scheme 1 